\title{
MENINGKATKAN KREATIVITAS BELAJAR SISWA MENGGUNAKAN MODEL COOPERATIVE SCRIPT DALAM PELAJARAN IPA DI KELAS IV SD NEGERI 107403 CINTA RAKYAT
}

\author{
Khairul Anwar, Nita Yanti \\ *Dosen Jurusan PPSD Prodi PGSD FIP UNIMED \\ **Mahasiswa Jurusan PPSD Prodi PGSD FIP UNIMED \\ Surel: khairulanwar25@yahoo.co.id
}

\begin{abstract}
Abstrak
Penelitian ini bertujuan untuk meningkatkan kreativitas belajar siswa pada mata pelajaran IPA materi pokok energi dan kegunaannya. Subjek dalam penelitian yaitu siswa kelas IV SD Negeri 107404 Cinta Rakyat Kec. Percut Sei Tuan T.A 2014/2015, yang berjumlah 26 orang siswa. Penentuan subjek berdasarkan hasil observasi dan angket yang diakukan peneliti terhadap guru kelas IV. Hasil penelitian menunjukkan pada Siklus I pertemuan I kreativitas belajar siswa tergolong rendah dengan nilai rata-rata $(19,23 \%)$, siklus I pertemuan II nilai rata-rata $(47,88 \%)$. Siklus II pertemuan I kreativitas belajar siswa tergolong tinggi dengan nilai rata-rata $(60,00 \%)$, sedangkan siklus II pertemuan II nilai rata-rata $(88,46 \%)$. Dari hasil yang diperoleh dapat disimpulkan bahwa dengan menggunakan Model Cooperative Script dapat meningkatkan kreativitas belajar siswa pada pelajaran IPA materi pokok energi dan kegunaannya di kelas IV SD Negeri 107403 Cinta Rakyat Kec. Percut Sei Tuan.
\end{abstract}

Kata Kunci : Kreativitas Belajar, Model Cooperative Script

\section{PENDAHULUAN}

Pendidikan merupakan salah satu usaha yang bertujuan untuk mencerdaskan kehidupan bangsa, dan merupakan suatu kunci pokok untuk mencapai cita - cita suatu bangsa. Untuk mewujudkan cita cita tersebut tentunya perlu usaha yang maksimal dari guru, dimana pada saat menyampaikan pelajaran guru mampu membangkitkan minat dan keantusiasan siswa dalam belajar, sehingga terciptanya siswa yang terampil dan berintelektual. Tetapi kenyataannya hal tersebut tidak tercapai. Hal ini dapat dilihat dari kreativitas pembelajaran sehari - hari di kelas .

Salah satu yang di hadapi bangsa Indonesia pada saat ini adalah rendahnya mutu pendidikan pada setiap jenjang dan suatu pendidikan, khususnya pendidikan di sekolah dasar .

Pembelajaran IPA merupakan pembelajaran yang menempatkan aktivitas nyata anak dengan berbagai objek yang dilihat dan di pelajari, merupakan hal utama yang perlu dikembangkan. Dalam pembelajaran seperti ini anak langsung berbuat dan belajar mengenai apa yang akan di pelajari. Siswa di bimbing oleh guru tentang pelajaran yang akan di pelajarin, mencari masalah tentang materi yang akan di pelajarin, mengembangkan kemampuan fisik (motorik) dan melatih penalaran kemampuan peserta didik. IPA berhubungan dengan cara mencari 
tahu tentang alam secara sistematis sehingga IPA bukan hanya penguasaan kumpulan pengetahuan yang berupa fakta - fakta, konsep konsep, atau prinsip - prinsip saja tetapi juga merupakan suatu proses penemuan. IPA di harapkan menjadi wahana bagi peserta didik untuk mempelajari diri sendiri dan alam sekitar.

Dalam kenyataannya banyak siswa yang tidak kreatif dalam belajar IPA, hal ini mungkin di karenakan oleh siswa tidak menyukai pelajaran IPA, harsat keinginanaya kurang dalam belajar, dan siswa kurang memiliki pemikiran yang kritis dalam belajar.

Berdasarkan wawancara Guru bidang studi IPA SD Negeri 107403 Cinta Rakyat nilai ulangan harian IPA siswa kelas IV sebanyak 20 orang masih rendah, dimana siswa 8 (40\%) yang memenuhi kriteria ketuntasan minimal (KKM) yaitu nilai 60 dan masih terdapat 12 siswa yang tidak memenuhi kriteria KKM. Hal ini menunjukkan bahwa hasil belajar IPA siswa masih kurang memuaskan.

Berdasarkan observasi dan angket kreativitas yang diberikan kepada siswa dengan indikator hasrat keinginantahuan yang besar, bahwa 3 (15\%) siswa menjawab sangat baik dan $2(10 \%)$ siswa menjawab baik, dan $5(25 \%)$ siswa menjawab cukup. Hal ini dapat dihubungkan dengan hasil wawacancara dari guru, bahwa masih terdapat 12 siswa yang tidak memenuhi kriteria KKM. Maka dapat dikatakan masih banyak siswa yang harsat keinginan tahuanya kurang dalam belajar. Berdasarkan indikator cenderung mencari jawaban yang luas dan memuaskan, bahwa $3(15 \%)$ orang siswa menjawab sangat baik dan $4(20 \%)$ siswa menjawab baik, dan $3(15 \%)$ siswa menjawab cukup. Hal ini dapat dihubungkan dengan hasil wawacancara dari guru, bahwa masih terdapat 10 siswa yang tidak memenuhi kriteria KKM. Maka dapat dikatakan masih banyak siswa yang kurang cenderung berkreativitas mencari jawaban yang memuaskan dalam belajar, Serta indikator menanggapi pertanyaan yang diajukan oleh guru, bahwa 1 $(5 \%)$ orang siswa menjawab sangat baik dan $2(10 \%)$ siswa menjawab baik, dan $3(15 \%)$ siswa menjawab cukup. Hal ini dapat dihubungkan dengan hasil wawacancara dari guru, bahwa masih terdapat 14 siswa yang tidak memenuhi kriteria KKM. Maka dapat dikatakan masih banyak siswa yang kurang menjawab pertanyaan yang diberikan oleh guru dalam proses belajar mengajar. Sedang indikator memiliki daya atraksi yang baik.

Dari data di atas dapat
disimpulkan kemampuan kreativitas belajar siswa pelajaran IPA siswa masih rendah. Pada dasarnya banyak faktor yang mempengaruhi rendahnya kreativitas belajar siswa dalam belajar IPA, disebabkan karena guru kurang memberikan kesempatan kepada 
siswa untuk bertanya. Faktor lainnya adalah mata pelajaran IPA merupakan salah satu mata pelajaran yang sangat sulit, membosankan dan tidak ada manfaat yang di rasakan siswa dalam belajar IPA. Hal ini disebabkan karena guru cenderung menggunakan metode ceramah yang proses pembelajarannya berpusat pada buku yang ada. Selama pembelajaran, guru juga kurang memberikan kesempatan kepada siswa untuk bertanya dan mengungkapkan ide atau gagasan mereka, serta kurang memberikan tantangan kepada siswa untuk mampu berpikir secara kreatif melalui tugas-tugas atau pertanyaan -pertanyaan yang di berikan, sehingga siswa lebih banyak pasif sebagai mendengar dengan memperhatikan dan mencatat apa yang disampaikan guru. Serta siswa kurang harsat keinginantahuannya dalam proses pembelajaran berlangsung, kebosanan siswa juga terlihat dari banyaknya siswa yang sering sibuk sendiri dengan teman sebangkunya daripada mendengarkan penjelasan dari guru dan tidak semangat menjawab pertanyaan yang diajukan oleh guru.

Untuk mengatasi permasalahan tersebut, maka diperlukan model pembelajaran yang berguna untuk meningkatkan kreativitas belajar siswa secara optimal yaitu dengan menggunakan model Cooperative Script. Dengan adanya model pembelajaran ini di harapkan siswa mampu mengembangkan kreativitas belajar dalam menyelesaikan soal soal IPA . Karena kreativitas itu merupakan kemampuan individu untuk menciptakan sesuatu hal yang baru dan berbeda, kreatif siswa berbeda -beda, siswa memiliki kreativitas yang tinggi, dan dapat menciptakan cara belajar dengan baik, dapat menciptakan cara belajar dengan mudah serta mampu memahami penyelesaian soal - soal yang di hadapi dalam belajar. proses pembelajaran dapat berlangsung dengan baik dan aktif .

Berdasarkan uraian diatas, maka peneliti tertarik menerapkan model pembelajaran tersebut dan penulis tertarik untuk melakukan penelitian dengan judul tentang "Meningkatkan Kreativitas Belajar Siswa dengan Menggunakan Model Cooperative Script dalam Pelajaran IPA Kelas IV SDN. 107403 Cinta Rakyat T.A 2014/2015."

\section{METODOLOGI PENELITIAN}

Penelitian ini adalah penelitian tindakan kelas (PTK) yang bertujuan untuk memperbaiki proses pembelajaran dalam meningkatkan minat belajar siswa dalam pelajaran IPA pada materi pokok energi dan penggunaannya dengan menggunakan model pembelajaran Cooperative Script di kelas IV SD Negeri 107403 Cinta Rakyat Kec. Percut Sei Tuan .

Sesuai dengan jenis penelitian tindakan kelas, maka penelitian ini memiliki beberapa tahapan yang merupakan suatu 
siklus. Tiap siklus dilaksanakan berdasarkan perubahan yang akan dicapai. Pada penelitian ini akan dilaksanakan dalam dua siklus yakni siklus I dan siklus II. Prosedur Penelitian ini menggunakan beberapa tahapan yakni dimulai dari perencanaan, pelaksanaan tindakan, pengamatan dan terakhir refleksi. Alat pengumpulan data yang digunakan pada penelitian ini adalah observasi dan angket.

\section{Siklus I}

\section{Perencanaan}

Melatih rendahnya kreativitas belajar siswa upaya yang di lakukan guru untuk kegiatan belajar mengajar di lakukan sebagai berikut :

a. Menetapkan topik atau masalah serta tujuan yang hendak di capai

b. Menyusun rencana pembelajaran sesuai dengan materi pelajaran

c. Menyusun alat observasi kegiatan mengajar guru dan aktivitas belajar siswa

d. Mempersiapkan media yang diperlukan

e. Mempersiapkan indikator/ deskriptor minat belajar siswa

\section{Pelaksanaan}

Sebelum proses pembelajaran dengan menggunakan model pembelajaran Cooperative Script di laksanakan guru terlebih dahulu mengatur tempat duduk siswa, dan mengucapkan salam .

Pemberian Tindakan
Sebagai tindakan awal, guru melakukan apersepsi dan memotivasi agar bersungguh - sungguh dalam mengikuti proses belajar mengajar. Bentuk apersepsi yang di lakukan yaitu dengan bernyanyi dan menunjuk beberapa orang siswa agar menjawab soal yang diajukan guru. Secara bersamaan guru juga memotivasi siswa yang mampu menjawab pertanyaan seperti “ jawaban kamu benar, jawaban kamu bagus sekali “

Selanjutnya guru menjelaskan materi pembelajaran, pengertian energi dan penggunaannya. Guru juga menjelaskan tentang sumber sumber energi dan penggunaanya, kemudian guru menjelaskan macam - macam energi dan penggunaanya, dan guru memberikan contoh contoh dari energi dan penggunaanya.

\section{Pengamatan}

Berdsarkan table di atas maka dapat di jelaskan bahwa aktivitas belajar siswa selama siklus 1 tinggi dengan nilai $47,88 \%$. Walaupun demikian masih di temukan beberapa indikator / deskriptor dari aktivitas belajar siswa yang tergolong rendah oleh karenanya guru perlu mengaktifkan kegiatan siswa pada siklus berikutnya.

\section{Refleksi}

Berdasarkan hasil observasi pada siklus I, maka peneliti melakukan refleksi terhadap seluruh kegiatan pada sikus I. 
Hanya sebagian kecil siswa yang mau berpartisipasi memikirkan pemecahan masalah tentang model Cooperative Script yang diajukan pada setiap sekelompok dan hanya beberapa siswa yang senang terhadap diskusi. Guru kurang memberikan arahan kepada siswa tentang langkah model Cooperative Script.

(1) Banyak siswa bingung menyelesaikan tahap demi tahap pembelajaran dengan penerapan model Cooperative Script, karena guru tidak menjelaskan bagaimana cara-caranya menyelasikannya. (2) siswa juga masih belum berani untuk mengungkapkan pendapatnya, karena guru tidak memberikan kesempatan kepada siswa untuk mengeluarkan pendapatnya. siswa masih cenderung diam dan sulit berkomunikasi, karena guru tidak melibatkan siswa dalam belajar. (4) Siswa masih "tunjuk tunjukkan" dengan temannya ketika guru menyuruh siswa untuk mempresentasekan hasil kerjanya didepan kelas, karena guru tidak membiasakan siswa untuk memberanikan maju kedepan. (5) Siswa kurang percaya diri dengan hasil jawabannya sendiri, hal ini dilihat sebagain siswa mengganti jawabannya dengan jawabannya temannya, karena guru tidak memberikan contoh kepada siswa bagaimana cara bersifat jujur dan bercaya diri dalam diri kita.

Hal ini diperkuat dengan data yang diperoleh berdasarkan hasil observasi pada siklus I, hasrat keinginantahuan yang besar, cenderung mencari jawaban yang luas dan memuaskan, keinginan untuk menemukan dan meneliti, menanggapi pertanyaan yang diajukan dan memiliki daya atraksi yang baik masih tergolong rendah. Hasil observasi kreativitas siswa pada siklus I rata-rata kreativitas siswa hanya $23,07 \%$. Kriteria ini masih tergolog cukup yang belum seseuai dengan harapan. Dengan perincian 4 orang siswa $(15 \%)$ memperoeh krieriaa sangat baik, 13 orang siswa (50\%) memperoleh kriteria baik, 7 orang siswa (27\%) yang memperoleh kriteria sedang, dan 2 orag siswa (8\%) yang memperoleh kriteria rendah. Dengan demikian, pada pelaksanaan siklus II perlu adanya inovasi dari tahapan model cooperative script yang dapat mendorong siswa lebih aktif dan kreatif.

\section{Siklus II}

\section{Perencanaan}

Berdasarkan hasil refleksi pada siklus 1 yang telah di identifikasi, dapat di tarik kesimpulan bahwa ada beberapa tindakan pembelajaran yang perlu mendapatkan revisi atau perbaikan. Hal ini dapat di lihat masih rendahnya kreativitas belajar berlangsung selama penggunaan model cooperative script berlangsung. Melihat rendahnya kreativitas belajar siswa maka upaya yang di lakukan guru dalam menumbuhkan kreativitas belajar siswa di lakukan dengan cara sebagai berikut ini : 
a. Mengembangkan materi ajar dan menyiapkan rencana pelaksanaan pembelajaran.

b. Mempersiapkan media pembelajaran.

c. Mempersiapkan indikator / desriptor penilaian terhadap tulisan siswa.

d. Mempersiapkan aktivitas belajar mengajar guru selama menggunakan model Cooperative Script.

e. Mempersiapkan lembar observasi terhadap aktivitas belajar siswa selama proses belajar mengajar berlangsung.

f. Mempersiapkan indikator/deskriptor kreativitas belajar siswa .

g. Mempersiapkan angket kreativitas belajar siswa.

\section{Pelaksanaan}

Selanjutnya guru menjelaskan materi pelajaran energi dan penggunaannya, guru juga menjelaskan manfat dan macam macam energi beserta fungsinya, setelah guru menjelaskan materi pelajaran guru kemudian menanyakan kepada siswa tentang energi dan kegunaannya yang pernah mereka ketahui .

Selanjutnya guru menjelaskan materi pembelajaran, manfaat energi dan kegunaanya kepada setiap ketua kelompok dan guru juga dapat menunjukan contoh secara kongkrit manfaat energi dan kegunaannya kepada seluruh siswa, setelah guru menjelaskan apa manfaat energi, dan macam - macam energi dan kegunaannya, kemudian setiap ketua kelompok mempunyai kewajiban untuk dapat mempesentasekan materi yang telah diberikan oleh guru tadi. Kemudian kelompok lain memberikan pertanyaan kepada yang telah memperesentasekan di depan kelas dan dapat di dengar oleh setiap anggota kelompok lainnya .

\section{Pengamatan}

Berdasarkan table di atas maka di jelaskan bahwa kemampuan guru dalam melakukan proses pembelajaran dengan menggunakan model cooperative script. selama siklus II tergolong sangat tinggi dengan nilai rata - rata 90,62\% . Melihat data temuan penelitian ini maka guru tidak perlu melanjutkan pada siklus berikutnya

\section{Refleksi}

Berdasarkan hasil siklus II dalam hal refleksi peneliti bersama observejr bekumpul untuk merefleksi tindakan yang telah dilaksanakan oleh peneliti. Dari hasil pengamatan tindakan yang dilaksanakan peneliti dari berbagai aspek kreativitas belajar siswa menunjukkan adanya peningkatan.

Berdasarkan tabel di atas maka dapat di ketahui bahwa dari 26 orang siswa secara klasikal terdapat 8 orang siswa $(62,5 \%)$ yang memperoleh kriteria sangat tinggi, sebanyak 13 orang siswa $(38,47 \%)$ yang memperoleh kriteria tinggi, sedangkan 5 orang siswa (100\%) yang memperoleh kriteria cukup. Hasil observasi kegiatan megajar guru pada siklus II $(80,77 \%)$. 
Dengan demikian dapat dinyatakan bahwa kreativitas belajar siswa meningkat dalam pelajaran IPA materi energi dan kegunaannya dengn menggunakan model Cooperative Script.

Dari hasil pembelajaran pada siklus II di lakukan maka dapat disimpulkan terdapat peningkatan hasil belajar siswa pada siklus II dibandingkan dengan siklus I, pada pelaksanaan siklus II perubahan yang di alami adalah sebagai berikut : (1) siswa dapat mengerjakan soal-soal yang diberikan oleh guru, karena guru sudah menjelaskan bagaimana cara-cara mengerjakannya, (2) siswa berani mengungkapkan pendapatnya, karena guru sudah memberikan kesempatan kepada siswa untuk mengeluarkan pendapatnya, siswa berani berkomunikasi dengan guru, karena guru sudah melibatkan siswa dalam belajar mengajar, (4) Siswa tidak "tunjuk -tunjukkan" dengan temannya ketika guru menyuruh siswa untuk mempresentasekan hasil kerjanya didepan kelas, karena guru sudah membiasakan siswa untuk memberanikan maju kedepan, (5) siswa percaya diri dengan hasil jawabannya sendiri, Karena guru sudah memberikan contoh kepada siswa bagaimana cara bersifat jujur dan bercaya diri dalam diri kita.

Untuk mengetahui tingkat perubahan kreativitas belajar siswa selama awal tindakan, siklus 1, siklus II dapat di lihat pada table berikut ini :
Tabel 4.20 Rekapitulasi Persentase Perubahan Kreativitas Belajar Siswa Pada Kondisi Awal, Siklus I dan Siklus II

\begin{tabular}{|c|c|c|c|l|}
\hline Kode & $\begin{array}{c}\text { Kondisi } \\
\text { Awal }\end{array}$ & Siklus I & Siklus II & Kerterangan \\
\hline 1 & 30 & 48,3 & 60 & Meningkat \\
\hline 2 & 23 & 80 & 75 & $\begin{array}{l}\text { Tidak } \\
\text { Meningkat }\end{array}$ \\
\hline 3 & 31 & 67,5 & 50 & $\begin{array}{l}\text { Tidak } \\
\text { Meningkat }\end{array}$ \\
\hline 4 & 33,33 & 47 & 88,33 & Meningkat \\
\hline 5 & 37,5 & 77,5 & 65,83 & $\begin{array}{l}\text { Tidak } \\
\text { Meningkat }\end{array}$ \\
\hline 6 & 30 & 41,66 & 70,83 & Meningkat \\
\hline 7 & 25 & 66,66 & 52,5 & $\begin{array}{l}\text { Tidak } \\
\text { Meningkat }\end{array}$ \\
\hline 8 & 50 & 80,83 & 79,16 & $\begin{array}{l}\text { Tidak } \\
\text { Meningkat }\end{array}$ \\
\hline 9 & 41,66 & 50 & 63,33 & Meningkat \\
\hline 10 & 66,66 & 75,83 & 91,66 & Meningkat \\
\hline 11 & 70,83 & 47 & 69,16 & Meningkat \\
\hline 12 & 75 & 30 & 88,33 & Meningkat \\
\hline 13 & 58,33 & 75 & 67,5 & $\begin{array}{l}\text { Tidak } \\
\text { Meningkat }\end{array}$ \\
\hline 14 & 54,16 & 26 & 68,33 & Meningkat \\
\hline 15 & 17 & 45,83 & 80 & Meningkat \\
\hline 16 & 25 & 62,5 & 55 & $\begin{array}{l}\text { Tidak } \\
\text { Meningkat }\end{array}$ \\
\hline 17 & 29,16 & 65 & 78,33 & Meningkat \\
\hline 18 & 33,33 & 49,16 & 91,66 & Meningkat \\
\hline 19 & 41,66 & 68,33 & 70 & Meningkat \\
\hline 20 & 12,5 & 85 & 77,5 & $\begin{array}{l}\text { Tidak } \\
\text { Meningkat }\end{array}$ \\
\hline 21 & 62,5 & 50 & 85,83 & Meningkat \\
\hline 22 & 30 & 25 & 70 & Meningkat \\
\hline 23 & 33,33 & 47 & 89,16 & Meningkat \\
\hline 24 & 37,5 & 83,33 & 66,66 & $\begin{array}{l}\text { Tidak } \\
\text { Meningkat }\end{array}$ \\
\hline 25 & 29,16 & 26,66 & 83,33 & Meningkat \\
\hline 26 & 33,33 & 75,5 & 58,33 & $\begin{array}{l}\text { Tidak } \\
\text { Meningkat }\end{array}$ \\
\hline
\end{tabular}

Berdasarkan tabel diatas memperlihatkan adanya peningkatan persentase kreativitas belajar siswa dari Kondisi Awal, siklus I, dan siklus II. Pada Kondisi Awal diperoleh nilai rata-rata kreativitas belajar siswa $33,42 \%$, siklus I diperoleh nilai rata-rata kreativitas belajar siswa $57,36 \%$ sedangkan 
pada siklus II diperoleh nilai rata-rata kreativitas belajar siswa 72,92\%.

Dari tabel diatas dapat diamati bahwa terdapat peningkatan kreativitas belajar. Jadi dapat disimpulkan bahwasanya melalui hasil penelitian memberikan jawaban bahwa dengan penggunaan model cooperative script pada pelajaran IPA materi energi dan penggunaannya dapat meningkatkan kreativitas belajar siswa.

\section{SIMPULAN DAN SARAN}

\section{Simpulan}

Berdasarkan hasil temuan dan data penelitian yang dilakukan terhadap peningkatan kreativitas belajar siswa pada pokok bahasan energi dan kegunaannya dengan menggunakan model Cooperative Script di SD Negeri 107403 Cinta Rakyat, maka peneliti membuat kesimpulan sebagai berikut :

a. Pembelajaran dengan model Cooperative Script dapat meningkatkan kreativitas belajar siswa dalam mata pelajaran IPA materi pokok energi dan kegunaannya.

b. Dengan model cooperative script dalam pembelajaran IPA dapat meningkatkan kreativitas belajar siswa. Hal ini dapat ilihat adanya peningkatan pada 5 indikator kreativitas belajar yaitu : 1) hasrat keinginantahuan yang besar, 2) cenderung mencari jawaban yang luas dan memuaskan, 3) keinginan untuk menemukan dan meneliti, 4) menenggapi pertanyaan yang diajukan, 5) memiliki daya atraksi yang baik.

c. Dengan model cooperative script pada pembelajaran IPA dapat meningkatkan kualitas proses pembelajaran yang dilakukan guru dan peningkatan kualitas hasil belajar siswa.

d. Rata-rata kelas kreativitas belajar siswa yang diajarkan dengan menggunakan model cooperative script lebih baik daripada sebelumnya. Hal ini tersebut dari siklus I pertemuan I diperoleh 5 orang siswa yang memiliki kreativitas belajar siswa yaitu dengan nilai rata-rata $(19,23 \%)$, sedangkan siklus I pertemuan II di peroleh 6 orang siswa yang memiliki kreativitas belajar siswa yaitu dengan nilai rata-rata $(23,07 \%)$.

e. Pada siklus II pertemuan I diperoleh 16 orang siswa yang memiliki kreativitas belajar siswa yaitu dengan nilai rata-rata (61,53\%), sedangkan pada siklus II pertemuan II mengalami perubahan meningkat dan sesuai dengan persentase yang ingin dicapai pada tingkat kreativitas belajar siswa, yaitu 23 orang siswa memiliki kreativitas belajar baik $(88,46 \%)$.

f. Pada siklus I pertemuan I nilai rata-rata pada observasi guru terdapat 38,28\% tergolong masih rendah, sedangkan pad siklus I pertemuan II mengalami sedikit peningkatan dengan nilai ratarata 59,37\%. Dan Pada siklus II 
pertemuan I nilai rata-rata pada observasi guru terdapat $64,84 \%$ tergolong masih tinggi, sedangkan pada siklus II pertemuan II mengalami peningkatan dengan nilai ratarata $90,62 \%$.

\section{Saran}

Berdasarkan hasil penelitian dan kesimpulan di atas, dapat dikemukan beberapa saran yaitu :

a. Kepada sekolah memberikan pelatihan, menerangkan program-program pelatihan untuk peningkatkan keterampilan guru dalam penerapan model cooperative script untuk meningkatkan kreativitas belajar siswa.

b. Sebaiknya guru menggunakan model cooperative script dalam pembelajaran dengan menyesuaikan materi yang diajarkan.

c. Sebaiknya siswa lebih aktif dalam pembelajaran serta berlomba-lomba dalam meningkatkan kreativitas belajarnya.

d. Bagi peneliti sendiri, sekiranya hasil penelitian tindakan kelas ini dapat dijadikan suatu keterampilan serta pengetahuan untuk menambah wawasan dalam mendidik siswa SD.

\section{DAFTAR RUJUKAN}

Al-hajjaj. 2010. Beajar Kreatif. http://miftahulsakina.

Wordpres.com

Aqib, Zainal. 2013. Model-Model. Media. dan Strategi Pembelajaran Kontekstual. Bandung: Yrama Widya.

Arikunto, S. Suhardjono dan Supardi. 2010. Peneltian Tindakan Kelas. Jakarta: Bumi Aksara.

Azam, Much. 2012. Ilmu

Pengeahuan Alam. Solo: Latimun

Dewi, Rosmala. 2010. Penelitian Tindakan Kelas. Medan: Pasca Sarjana Unimed

Hurlock, Elizabeth. 2010.

Perkembangan Anak. Jakarta: Erlangga

Istarani. 2012. 58 Model

Pembelajaran Inovatif.

Medan: Media Persada.

Ngalimun. 2013. Strategi dan Model Pembelajaran. Yogyakarta: Aswaja Pressindo.

Ridwan. 2010. Belajar Mudah

Penelitian. Bandung: Alfabeta.

Rusman. 2011. Model - model Pembelajaran

Mengembangkan

Profesionalisme

Guru.

Jakarta: Rajawali Pers.

Sani Abdullah Ridwan. 2013. Inovasi

Pembelajaran. Jakarta:

Bumi Aksara.

Slameto. 2010. Belajar dan Faktor-

Faktor yang

Mempengaruhinya. Jakarta:

Rhineka

Cipta. 
